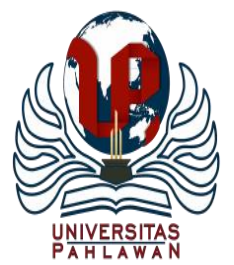

Edukatif : Jurnal Ilmu Pendidikan Volume 3 Nomor 5 Tahun 2021 Halm 2531 - 2538

EDUKATIF: JURNAL ILMU PENDIDIKAN

Research \& Learning in Education

https://edukatif.org/index.php/edukatif/index

\title{
Pengaruh Penggunaan Media Audio Visual Animaker terhadap Motivasi Belajar IPA Siswa Sekolah Dasar
}

\author{
Galuh Maheswari $^{1 凶}$, Puri Pramudiani ${ }^{2}$ \\ Universitas Muhammadiyah Prof. Dr. Hamka, Indonesia ${ }^{1,2}$ \\ E-mail : galuhmahes9@ gmail.com ${ }^{1}$, puri.pramudiani@uhamka.ac.id ${ }^{2}$
}

\begin{abstract}
Abstrak
Penelitian ini bertujuan untuk dapat mengetahui ada atau tidaknya pengaruh penggunaan media audio visual animaker terhadap motivasi belajar IPA siswa kelas IV SDN Pekayon 12. Penelitian ini dilatarbelakangi dengan adanya penelitian sebelumnya yang menunjukkan bahwa sebuah motivasi belajar siswa belum sesuai dengan yang diharapkan. Metode penelitian yang digunakan adalah kuantitatif dengan desain penelitian PostTest Only Control Design. Jumlah sampel pada penelitian berjumlah 46 peserta didik yaitu kelas IV B yang berjumlah 23 peserta didik sebagai kelas kontrol dan IV D yang berjumlah 23 peserta didik sebagai kelas eksperimen. Dalam perhitungan data analisis prasyarat penelitian menggunakan uji normalitas, homogenitas menggunakan uji-f, dan hipotesis uji-t. Hasil perhitungan hipotesis menggunakan Uji-t dinyatakan kedua kelas menunjukkan $t_{\text {hitung }}$ sebesar 6,514 > $t_{\text {tabel }}$ sebesar 1,680. Maka dapat disimpulkan $H_{1}$ diterima. Berdasarkan hasil penelitian ini dapat dibuktikan bahwa terdapat pengaruh penggunaan media audio visual animaker terhadap motivasi belajar IPA siswa kelas IV SDN Pekayon 12.
\end{abstract}

Kata Kunci : Media Audio Visual Animaker, Motivasi Belajar, IPA.

\section{Abstract}

This study aims to determine the effect of media audio-visual animaker on the science learning motivation of fourth grade students at SDN Pekayon 12. This background of this research based on previous studies showing that students's learning motivation was not as expected. The research method used was quantitative research design with Post-Test Only Control Design. The number of samples in the study amounted to 46 students, namely class IV B which amounted to 23 students as the control class and IV D, which amounted to 23 students as the experimental class. In calculating the research prerequisite analysis data used the normality test, homogeneity using the f-test, and the t-test hypothesis. The results of the hypothesis analysis using t-test stated that the two classes showed tcount of $6.514>t_{\text {table }}$ of 1.680 . Therefore, it can be concluded that HI is accepted. This study proves that there is an effect of using media audio-visual animaker on the science learning motivation of fourth grade students at SDN Pekayon 12.

Keywords: Media Audio-visual Animaker, Learning Motivation, Science.

Copyright (c) 2021 Galuh Maheswari, Puri Pramudiani

$\triangle$ Corresponding author

Email : galuhmahes9@gmail.com

DOI $\quad$ : https://doi.org/10.31004/edukatif.v3i5.872

ISSN 2656-8063 (Media Cetak)

ISSN 2656-8071 (Media Online) 
2532 Pengaruh Penggunaan Media Audio Visual Animaker terhadap Motivasi Belajar IPA Siswa Sekolah Dasar

- Galuh Maheswari, Puri Pramudiani

DOI : :https://doi.org/10.31004/edukatif.v3i5.872

\section{PENDAHULUAN}

Pendidikan merupakan upaya mempersiapkan peserta didik agar mampu berperan di masa yang akan datang melalui kegiatan bimbingan, pengajaran, dan pelatihan. Dalam proses pembelajaran, peserta didik tidak lepas dari bimbingan yang diarahkan oleh pendidik atau lebih dikenal dengan sebutan guru. Pendidik merupakan karakter utama dalam proses pembelajaran, keberhasilan peserta didiknya merupakan salah satu bentuk yang ada dalam program pendidikan. Untuk dapat menciptakan keberhasilan diperlukan kondisi pembelajaran yang optimal, pendidik harus memiliki ide-ide kreatif dan inovasi dalam menyampaikan materi yang disajikan serta mengetahui kriteria dalam memilih media pembelajaran.

Dalam menyampaikan isi atau materi pembelajaran di kelas, proses pembelajaran membutuhkan kehadiran media. Menurut pendapat Zayyadi dkk., (2017) menyatakan bahwa "Media pembelajaran adalah sesuatu yang terdiri dari bahan, alat atau teknik yang digunakan dalam kegiatan belajar mengajar dan membantu siswa memahami masalah yang abstrak". Berfungsi sebagai alat belajar sekaligus sebagai sumber belajar yang dapat dijadikan sebagai wadah bahan belajar bagi siswa. Dalam memilih media pembelajaran harus disesuaikan dengan materi pelajaran, situasi, dan kondisi yang berpengaruh besar terhadap prestasi.

Salah satu mata pelajaran yang penting di sekolah dasar adalah IPA. Ilmu Pengetahuan Alam (IPA) merupakan mata pelajaran utama yang terdapat dalam kurikulum pendidikan sekolah dasar (SD) di Indonesia. Menurut Permendikbud Nomor 58 tahun 2014 dinyatakan bahwa "IPA merupakan mata pelajaran yang dimulai dari jenjang Sekolah Dasar hingga jenjang Sekolah Menengah Atas". Ilmu Pengetahuan Alam disebut juga sebagai pengetahuan yang dihasilkan melalui proses kegiatan berupa fakta, konsep, dan teori. Proses pengajaran kepada peserta didik di kelas melakukan penelitian yang dilakukan sendiri oleh peserta didik, maka mata pelajaran IPA tidak bersifat hafalan belaka. Inilah sebabnya mengapa sulit bagi pendidik untuk mengajarkan sains di sekolah dasar. Sehingga pendidik harus berusaha untuk dapat mengubah cara penyampaian materi atau isi dalam pelajaran IPA dan mempermudah dalam menerima materi pembelajaran.

Membantu peserta didik untuk memahami sains secara lebih luas membutuhkan motivasi belajar. Menurut Muliastrini dkk., (2020) kenyataannya penyampaian materi pembelajaran masih cenderung menggunakan metode konvensional yang terkesan sederhana, respon siswa kurang baik, dan menyebabkan siswa tidak mau belajar. Dalam hal ini motivasi belajar dikatakan sangat penting karena dapat memicu kegiatan belajar, menjamin kelangsungan belajar, dan memberikan pedoman bagi motivasi belajar siswa secara keseluruhan, sehingga tujuan yang diharapkan dari objek pembelajaran dapat tercapai. Pendapat Patandung (2017) mengungkapkan "Motivasi belajar merupakan faktor yang banyak berpengaruh terhadap proses dan hasil belajar peserta didik serta berguna untuk mencapai keberhasilan belajar secara optimal.". sedangkan pendapat Fallah (2014) bahwa "Motivasi dikatakan kombinasi usaha serta keinginan untuk mencapai tujuan belajar yang didukung dengan sikap dalam menghadapi proses pembelajaran". Oleh sebab itu, apabila proses pembelajaran terhadap motivasi peserta didik dapat ditingkatkan maka kinerja peserta didik dapat menunjukkan hasil yang baik, begitu pula adanya alat bantu sangat mempengaruhi adanya keinginan belajar.

Berdasarkan hasil observasi yang dilakukan di kelas IV SDN Pekayon 12 terungkap bahwa penggunaan media terlihat sangat sederhana, pembelajaran yang disajikan hanya dengan gambar yang terdapat dalam buku siswa, motivasi belajar masih rendah, serta peserta didik belum mampu menghubungkan materi IPA dalam kehidupan sehari-hari. Sehingga dampak yang terjadi menyebabkan peserta didik kurang antusias, cenderung bosan dengan pembelajaran, dan kurang bersemangat sehingga membuat pembelajaran kurang diminati.

Dari latar belakang yang telah dipaparkan sebelumnya serta sebagai bagian dari inovasi atau kebaharuan dalam penelitian ini, maka diterapkan suatu media pembelajaran yang diharapkan mampu memotivasi siswa dalam pembelajaran IPA. Hal ini sesuai dengan apa yang dinyatakan oleh Syaparuddin \& Elihami (2020) bahwa media pembelajaran yang tepat dapat meningkatkan motivasi belajar siswa sehingga 
siswa mendapatkan umpan balik yang baik dalam proses belajar di kelas. Adapun media yang diterapkan dalam penelitian ini adalah media video animaker. Penggunaan media audio visual berperan dalam meningkatkan pemahaman terhadap isi atau materi pembelajaran yang diamati melalui indera penglihatan dan indera pendengar. Peserta didik juga dapat merasakan pengalaman langsung melalui media audio visual. Pada umumnya pembelajaran IPA membutuhkan media yang kreatif dan menyenangkan, agar peserta didik dapat merasakan pembelajaran sesuai dengan dirinya dan lingkungan sekitarnya agar dapat diterapkan dalam kehidupan sehari-hari.

Tujuan penelitian ini dilakukan untuk mengetahui pengaruh penggunaan media audio visual animaker terhadap motivasi belajar IPA siswa kelas IV SDN Pekayon 12 pada semester genap tahun ajaran 2020/2021. Motivasi belajar yang disampaikan oleh Pebriani (2017) bahwa motivasi belajar dikatakan sebagai dorongan yang berperan besar dalam belajar karena melahirkan seseorang yang berhasil sesuai dengan keinginan sendiri itu melalui sebuah motivasi. Itulah mengapa motivasi belajar sangat begitu penting.

Dalam kajian Mashuri (2009) bahwa beragam fitur yang menarik dimiliki pada software Animaker diantaranya animasi, gambar-gambar yang didukung musik, tersedia efek transisi yang lebih hidup, serta disediakannya software melalui website dengan proses pengolahan mudah dan murah. Dengan adanya media pembelajaran yang menarik dapat memberikan kesan baik pada peserta didik.

Berdasarkan fenomena di atas, terlihat bahwa pemilihan media audio visual animaker merupakan bentuk layanan untuk memudahkan peserta didik dalam memahami isi pembelajaran IPA serta cara untuk meningkatkan motivasi belajar peserta didik. Dengan kata lain, dari penelitian yang telah dilakukan sebelumnya melalui media audio visual animaker pendidik lebih mudah dalam melakukan cara perbaikan dan penyempurnaan proses pembelajaran. Maka dari uraian tersebut peneliti melakukan penelitian dengan mengkaji pengaruh penggunaan media audio visual animaker terhadap motivasi belajar IPA siswa kelas IV SDN Pekayon 12.

\section{METODE PENELITIAN}

Metode pada penelitian ini yang digunakan adalah metode penelitian kuantitatif. Menurut Emzir disajikan dalam jurnal Hermawan (2019) mengemukakan bahwa, "Penelitian kuantitatif merupakan sesuatu pendekatan penelitian yang secara primer dengan menggunakan paradigma post positivisme dalam pengembangan ilmu pengetahuan (seperti pemikiran tentang sebab akibat, reduksi kepada variabel, hipotesis serta pertanyaan spesifik, menggunakan strategi penelitian seperti eksperimen dan survei yang memerlukan data statistik.". Jenis penelitian ini adalah quasi eksperiment (eksperimen semu) menggunakan jenis Posstest Only Control Design.

Tabel 1. Desain Penelitian

\begin{tabular}{lcl}
\hline Kelompok & Perlakuan & Post Test \\
\hline Kelas Eksperimen & $\mathrm{X}$ & $\mathrm{O} 1$ \\
\hline Kelas Kontrol & & $\mathrm{O} 2$ \\
\hline
\end{tabular}

Keterangan :

$\mathrm{X} \quad$ : Perlakuan dengan menggunakan media audio visual animaker.

O1 : Hasil post-test menggunakan media audio visual animaker

O2 : Hasil post-test tanpa ada perlakuan

Proses penelitian berada di SDN Pekayon 12 pada semester genap tahun ajaran 2020/2021. Teknik yang digunakan dalam pengambilan sampel pada penelitian ini yaitu Probability Sampling dengan jenis teknik simple random sampling atau sampel sederhana. Populasi dilaksanakan di SDN Pekayon 12 dengan jumlah 46 
orang terdiri dari kelas IV B sebagai kelas kontrol berjumlah 23 orang dan kelas IV D sebagai kelas eksperimen berjumlah 23 orang. Pada penelitian ini teknik pengumpulan data melalui instrumen kuesioner (angket) serta dokumentasi. Kuesioner yang diberikan ke peserta didik digunakan untuk mengukur sikap seseorang dalam sebuah kejadian atau gejala yang diberikan melalui google form yang berisi daftar pertanyaan menggunakan skala likert. Sedangkan dokumentasi bertujuan untuk dapat melihat gambaran dengan visualisasi aktivitas dalam mencari data. Variabel bebas pada penelitian ini adalah penggunaan media audio visual animaker, sedangkan variabel terikat pada penelitian ini adalah motivasi belajar IPA. Dalam pengolahan data penelitian ini diukur melalui uji validitas serta reliabilitas bertujuan untuk mendapatkan soal valid atau tidaknya suatu butir angket dengan Alpha Cronbach. Teknik analisis data angket yang digunakan pada penelitian ini menggunakan uji normalitas, uji Fisher, dan uji-t dengan taraf signifikan 5\%.

\section{HASIL DAN PEMBAHASAN PENELITIAN}

Sebelum pelaksanaan penelitian dilakukan, diperlukan untuk uji coba instrumen angket yang akan disebarkan kepada peserta didik. Tujuan diadakan uji coba validitas instrumen untuk dapat melihat butir valid atau tidaknya dalam sebuah instrumen. Uji validitas dari instrumen angket diketahui siswa berjumlah 29 dan total keseluruhan butir soal sebanyak 30. Setelah diperhitungkan jumlah angket yang valid sebanyak 26 butir, sebagian butir angket tidak valid karena besarnya korelasi item dengan skor total lebih besar dari $\mathrm{t}_{\text {tabel }}=0,367$.

Tahap selanjutnya setelah uji validitas yaitu pengujian reliabilitas. Menurut Riduwan (2015) uji reliabilitas dimaksud untuk mengetahui apakah butir-butir tersebut telah valid dan memiliki sifat dipercaya. Dengan ketentuan angka Alpha Cronbach > 0,70 (Yusup, 2018) sehingga dapat dinyatakan instrumen tersebut reliabel. Motivasi belajar IPA memperoleh angka lebih besar dari 0,70 maka dalam artian hasil uji coba instrumen penelitian dinyatakan valid atau reliabel dengan butir soal 30 menjadi 26 butir soal. Dari data uji reliabilitas memperoleh $\mathrm{r}_{\text {hitung }}=0,919$ yang artinya data sangat reliabel karena telah memenuhi syarat $\mathrm{r}_{\text {hitung }}>$ 0,70 sehingga dapat dinyatakan data reliabel atau sangat tinggi.

Kegiatan penelitian ini dilakukan di SDN Pekayon 12 pada kelas IV B sebagai kelas eksperimen dan kelas IV B sebagai kelas kontrol. Kelas eksperimen yang diberikan perlakuan diterapkan media pembelajaran berupa media audio visual animaker sedangkan kelas kontrol menggunakan media pembelajaran pada umumnya. Sebelum penelitian ini dilakukan terlebih dulu untuk menetapkan materi pembelajaran serta menyusun rencana pelaksanaan pembelajaran yang akan diterapkan pada kelas eksperimen dan kelas kontrol. Mata pelajaran yang digunakan dalam penelitian adalah Ilmu Pengetahuan Alam (IPA) yang memuat pembahasan materi yaitu sumber energi, energi dan perubahannya, serta sumber energi alternatif.

Kemudian dalam penelitian ini menunjukkan hasil perolehan angket yang disajikan dalam sebuah deskripsi yang ada dalam kelas eksperimen serta kelas kontrol melalui Microsoft Excel pada tabel 1 sebagai berikut.

Tabel 2. Deskripsi Data Hasil Angket Kelas Eksperimen dan Kelas Kontrol

\begin{tabular}{lcc}
\hline \multicolumn{1}{c}{ Keterangan } & Kelas Eksperimen & Kelas Kontrol \\
\hline Nilai Tertinggi & 129 & 116 \\
\hline Nilai Terendah & 94 & 73 \\
\hline Mean & 118,348 & 97,435 \\
\hline Median & 123 & 98 \\
\hline Modus & 129 & 98 \\
\hline Varians & 114,783 & 124,711 \\
\hline Simpangan Baku & 10,714 & 11,167 \\
\hline $\mathrm{N}$ & 23 & 23 \\
\hline
\end{tabular}


Berdasarkan analisis data dalam tabel 1 maka hasil posttest angket tertinggi dicapai pada kelas eksperimen dengan diperoleh nilai tertinggi sebesar 129, dan nilai terendah sebesar 94, dan simpangan baku diperoleh sebesar 10,714 dengan jumlah data responden 23 peserta didik. Sedangkan di kelas kontrol diperoleh nilai tertinggi 116, nilai terendah 73, dan simpangan baku diperoleh sebesar 11,167 dengan jumlah data responden 23 peserta didik. Dalam hal ini deskripsi pada kelas eksperimen dengan kelas kontrol memiliki perbedaan yang signifikan.

Tahap berikutnya, perhitungan analisis data dengan menggunakan uji normalitas lilliefors. Pengujian ini dilakukan dengan taraf 0,05 atau 5\% dalam jumlah responden pada kelas eksperimen dan kelas kontrol dengan responden yang sama yaitu 23. Sehingga menunjukkan $L_{\text {hitung }}$ pada kelas eksperimen 0,109 dan $L_{\text {hitung }}$ pada kelas kontrol 0,069 maka data dinyatakan berdistribusi normal karena $L_{\text {hitung }}$ lebih kecil dari $L_{\text {tabel }}\left(L_{o}<L_{\text {tabel }}\right)$. Dengan hal ini kedua kelas hasil posttest pada kelas eksperimen dan kelas kontrol berdistribusi normal, sehingga dapat dilanjutkan dalam uji homogenitas.

Uji homogenitas memiliki tujuan untuk mengetahui pengukuran hasil dari varians apakah sama ataupun beda. Penelitian ini menggunakan uji homogenitas berupa uji fisher dengan kriteria bahwa $F_{\text {hitung }}<F_{\text {tabel. }}$. Dari hasil perhintungan kedua kelas, maka diperoleh nilai $F_{\text {tabel }}$ sebesar 2,03 dan harga $F_{\text {hitung }}$ sebesar 1,086 dengan $\mathrm{dk}$ pembilang $=22, \mathrm{dk}$ penyebut $=22$ serta taraf signifikan $\alpha=0,05$ atau $5 \%$. Itu artinya $F_{\text {hitung }}<F_{\text {tabel }}$ yaitu $1,086<2,03$ maka $H_{o}$ diterima sehingga dapat disimpulkan bahwa kedua data di atas bersifat homogen.

Setelah beberapa proses hasil uji prasyarat analisis (uji normalitasi dan uji homogenitas) menunjukkan bahwa kedua kelompok berdistribusi normal serta simpangan baku kelompok tersebut homogen. Uji selanjutnya adalah pengujian hipotesis penelitian dengan menggunakan Uji-t. Dalam buku (Ismail, 2018) tujuan pada perhitungan Uji-t bahwa untuk mengetahui terdapat atau tidaknya sebuah pengaruh dalam menggunakan media audio visual animaker terhadap motivasi belajar IPA. Kriteria pengujian $\mathrm{H}_{0} \mathrm{Jika}_{\mathrm{t}} \mathrm{t}_{\text {itung }}<$ $\mathrm{t}_{\text {tabel}}$, maka tidak terdapat pengaruh penggunaan media audio visual animaker terhadap motivasi belajar IPA siswa kelas IV SDN Pekayon 12. Sedangkan $\mathrm{H}_{1}$ jika $t_{\text {hitung }}>\mathrm{t}_{\text {tabel }}$, maka terdapat pengaruh penggunaan media audio visual animaker terhadap motivasi belajar IPA siswa kelas IV SDN Pekayon 12. Berikut tabel hasil perhitungan pada kelas eksperimen dan kelas kontrol.

Tabel 3. Data Hasil Uji Hipotesis

\begin{tabular}{lccccccc}
\hline \multicolumn{1}{c}{ Kelas } & Mean & $\mathrm{db}$ & $\mathrm{t}_{\text {hitung }}$ & $\mathrm{t}_{\text {tabel }}$ & Kriteria & Keputusan & Keterangan \\
\cline { 1 - 2 } Eksperimen & 118,348 & 44 & 6,514 & 1,680 & $6,514>1,680$ & $\mathrm{H}_{0}$ ditolak & Terdapat \\
Kontrol & 97,435 & & & & & & Pengaruh \\
\hline
\end{tabular}

Berdasarkan tabel 2. data hasil uji hipotesis, diperoleh $t_{\text {hitung }}$ pada kedua kelas sebesar 6,514 dan dan $t_{\text {tabel }}$ diperoleh sebesar 1,680. Kedua kelas menunjukkan $t_{\text {hitung }}$ sebesar 6,514 $>t_{\text {tabel }}$ sebesar 1,680. Maka dapat disimpulkan $H_{1}$ diterima bahwa kelas eksperimen yang diberikan perlakuan menunjukkan pengaruh penggunaan media audio visual animaker terhadap motivasi belajar IPA.

Sebuah pembahasan penelitian ini di dukung dengan penelitian relevan yang telah dilakukan oleh pihak Wahyullah Alannasir (2016) dalam penelitian "Pengaruh penggunaan media animasi dalam pembelajaran ips terhadap motivasi belajar siswa kelas IV SD Negeri Mannuruki", serta sejalan dengan Melia (2018) bahwa terdapat pengaruh Pengaruh media audio visual terhadap motivasi belajar peserta didik mata pelajaran fiqih kelas IV MI Al-Muhajirin Panjang Bandar Lampung.

Berdasarkan hasil perhitungan pengujian normalitas membuktikan kelas eksperimen diperoleh $\mathrm{L}_{\text {hitung }}<$ $\mathrm{L}_{\text {tabel }}(0,101<0,44)$ dengan taraf signifikan $=0,05$, sementara kelas kontrol dipeloleh $\mathrm{L}_{\text {hitung }}<\mathrm{L}_{\text {tabel }}(0,186<$ $0,444)$ dengan taraf signifikan $=0,05$. Maka hasil perhitunga kedua kelas berasal dari populasi berdistribusi normal. Tahap selanjunya, hasil perhitungan pengujian homogentias pada kelas eksperimen dan kelas kontrol pada $F_{\text {hitung }}(0,645)<\mathrm{F}_{\text {tabel }}(2,168)$ dengan taraf signifikan $=0,05$. Kemudian pada pengujian hipotesis dengan rumus uji-t diperoleh $t_{\text {hitung }}>t_{\text {tabel }}$ yaitu 3,409 > 2,024 dengan signifikan 0,05. Dapat disimpulkan bahwa $\mathrm{H}_{0}$ ditolak dan $\mathrm{H}_{1}$ diterima, dengan hal ini menunjukkan terdapat pengaruh media audio visual terhadap motivasi belajar. 
Sementara itu, perbedaan dalam penelitian sebelumnya bahwa desain penelitian menggunakan true eksperimen dengan jenis pretest post test dan nilai rata-rata kelas eksperimen 68,15 . Sedangkan penelitian ini menggunakan quasi eksperimen dengan jenis posstest only control design dengan hasil nilai rata-rata pada kelas eksperimen adalah 118,348. Yang mana penggunaan media audio visual animaker pada lingkungan tersebut belum mengenal serta tidak banyak yang memanfaatkan sebagai bentuk media pembelajaran. Pada umumnya media pembelajaran yang telah digunakan di beberapa sekolah masih terbilang menggunakan media powerpoint, serta buku cetak siswa, yang mana powerpoint disajikan oleh pendidik hanya berupa tulisan, dan gambar. Itulah mengapa penelitian ini menggunakan media audio visual animaker karena menyesuaikan dengan perkembangan teknologi saat ini. Media audio visual animaker pada pembelajaran IPA di SD yang telah dibuat oleh peneliti dapat diakses pada link berikut ini.
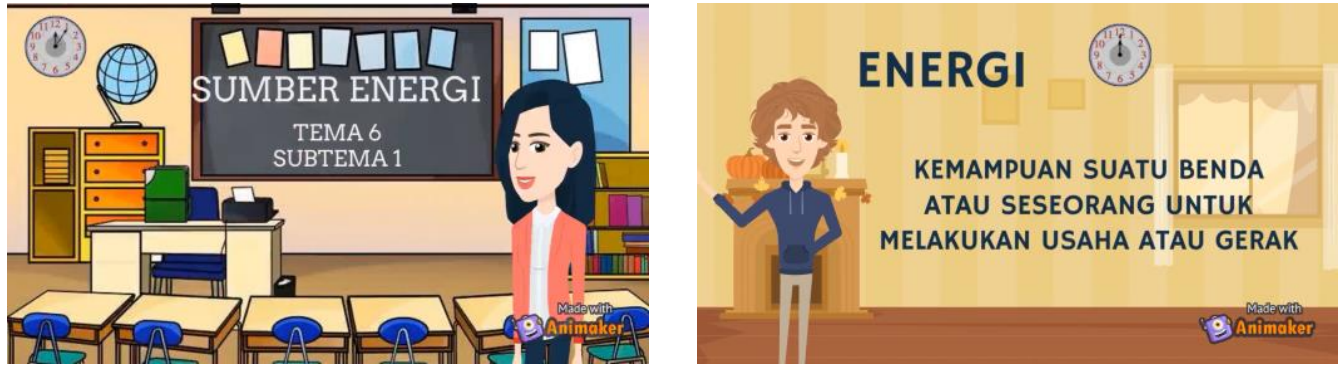

Gambar 1. Visualisasi Video Animaker dalam sub tema pembelajaran IPA https://www.youtube.com/watch?v=3pKIrODj1eQ \&t=114s

Berdasarkan hasil pengamatan yang telah dilakukan secara empiris maka diperoleh hasil bahwa kelas eksperimen yang menggunakan media audio visual animaker menunjukkan kegiatan proses pembelajaran peserta didik terlihat aktif, bergairah dalam belajar, serta menunjukkan sikap termotivasi pada saat pembelajaran berlangsung. Media audio visual yang diberikan di kelas eksperimen menyajikan audio visual animaker terdapat sebuah karakter-karakter yang unik seperti dalam sebuah animasi, memiliki transisi yang menarik, gerak dan suara yang membuat peserta didik memiliki ketertarikan dalam belajar IPA. Hal tersebut diperkuat dengan dukungan menurut Putri \& Desyandri (2019) mengatakan bahwa untuk menciptakan suasana belajar yang aktif, kreatif, serta menyenangkan pendidik perlu untuk lebih kreatif dan inovatif dalam rangka menciptakan media pembelajaran. Dengan upaya yang dilakukan pendidik, diharapkan dapat memberikan pengaruh untuk menciptakan keinginan belajar, membangkitkan motivasi belajar dan minat yang baru, serta membawa pengaruh baik dalam psikologi terhadap peserta didik. Kemudian dukungan ditunjukkan oleh Sukiyasa (2018) dalam temuannya berpendapat bahwa dengan menggunakan media animasi dapat meningkatkan motivasi belajar peserta didik. Sedangkan menurut Pratama,.dkk (2019) bahwa keberhasilan belajar siswa di kelas perlu ditingkatkan secara kontinu, motivasi belajar yang diperlukan untuk dapat menghasilkan yang baik dengan memberikan bahan ajar yang dikemas menjadi sebuah media pembelajaran yang menarik sesuai dengan usia peserta didik sehingga terjadi peningkatan minat belajar. Dengan hal ini, bahwa terlihat penggunaan media audio visual animaker dapat meningkatkan serta mempengaruhi motivasi belajar yang ada dalam diri peserta didik.

Keterbatasan dalam penelitian ini penelitian yang dilaksanakan secara virtual, peneliti sudah melakukan berbagai usaha untuk dapat melaksanakan sesuai dengan prosedur yang ada. Namun demikian peneliti memiliki beberapa keterbatasan diantaranya, adanya keterbatasan jaringan dan kuota internet yang dialami oleh peneliti dan siswa sehingga membuat pembelajaran yang ditampilkan kurang maksimal. kurangnya kontrol yang dilakukan oleh peneliti dikarenakan pembelajaran dilakukan secara virtual. Keterbatasan berikutnya adalah ketika akan melakukan pembelajaran melalui google meet tidak semua peserta didik dapat bergabung sehingga sebagian siswa yang tidak ikut diarahkan untuk menyimak melalui link youtube yang 
diberikan. Dengan semua keterbatasan yang ada penelitian ini melakukan sesuai dengan prosedur yang telah dirancang dengan baik sesuai dengan rencana pelaksanaan pembelajaran.

Motivasi belajar dalam penggunaan media audio visual animaker di kelas IV D sebagai kelas eksperimen dapat dikatakan berhasil diterapkan dalam proses pembelajaran karena media pembelajaran dikemas menarik sehingga peserta didik aktif dalam belajar, mudah menerima materi, memotivasi peserta didik agar memahami pembelajaran, serta peserta didik dapat merasakan pembelajaran langsung melalui audio visual animaker. Sama dengan pendapat Yusantika dkk,. (2018) menuturkan akan "Efektivitas yang terjadi dalam penggunaan media audio visual memberikan pelajaran yang bervariasi serta tidak monoton sehingga peserta didik dapat mengembangkan dan meningkatkan pemahaman pembelajaran secara mandiri.".

Keseluruhan hasil penelitian tersebut membuktikan bahwa pengaruh penggunaan media audio visual animaker memberikan pengaruh positif serta signifikan terhadap motivasi belajar IPA siswa kelas IV SDN Pekayon 12. Dengan demikian dalam penggunaan media audio visual animaker di kelas membuat pembelajaran menjadi lebih bervariasi sehingga peserta didik menjadi termotivasi dalam belajar.

\section{KESIMPULAN}

Berdasarkan penelitian di kelas IV SDN Pekayon 12 pada mata pelajaran IPA dapat disimpulkan bahwa terdapat pengaruh penggunaan media audio visual animaker terhadap motivasi belajar IPA di kelas IV SDN Pekayon 12. Kesimpulan dari pengolahan data statistika bahwa dinyatakan peserta didik menjadi termotivasi belajar IPA karena penggunaan media audio visual animaker merupakan media yang efektif digunakan dalam proses belajar mengajar baik jarak jauh maupun dekat. Penggunaan media audio visual animaker pada mata pelajaran IPA memudahkan bagi peserta didik dalam memahami materi pembelajaran yang disampaikan pendidik dalam proses pembelajaran daring, siswa menjadi aktif, pembelajaran menjadi menarik, peserta didik dapat merasakan pembelajaran langsung melalui audio visual animaker, serta video pembelajaran dapat dilihat sewaktu-waktu. Secara keseluruhan peserta didik dengan mudah memahami materi yang disampaikan oleh pendidik. Dalam hal penggunaan media audio visual animaker peserta didik dapat merasakan pembelajaran secara langsung yang dikemas dengan menarik menjadi video pembelajaran animasi serta peserta didik termotivasi dalam belajar IPA. Maka sebagai pendidik perlu menambah pengetahuan serta keterampilan mengenai media audio visual animaker yang digunakan baik dalam proses pembelajaran secara daring maupun tatap muka.

\section{DAFTAR ISI}

Fallah, N. (2014). Willingness To Communicate In English, Communication Self-Confidence, Motivation, Shyness And Teacher Immediacy Among Iranian English-Major Undergraduates: A Structural Equation Modeling Approach. Learning And Individual Differences, 30, 140-147. Https://Doi.Org/10.1016/J.Lindif.2013.12.006

Hermawan, I. (2019). Metodologi Penelitian Pendidikan Kuantitatif, Kualitatif, Dan Mixed Methode (C. S. Rahayu (Ed.)). Hidayatul Quran Kuningan.

Ismail, F. (2018). Statiska Untuk Penelitian Pendidkan Dan Ilmu-Ilmu Sosial ( Ed. . (M. Astuti (Ed.)). Prenadamedia Group.

Mashuri, D. K. (2009). Pengembangan Media Pembelajaran Video Animasi Materi Volume Bangun Ruang Untuk SD Kelas V. Pengembangan Media Video Animasi, 1-11.

Muliastrini, N. K. E., Handayani, N. N. L., \& Universitas Pendidikan Ganesha, 2STAHN Mpu Kuturan Singaraja. (2020). Widyalaya: Jurnal Ilmu Pendidikan. 1(1), 47-57.

Patandung, Y. (2017). Pengaruh Model Discovery Learning Terhadap Peningkatan Motivasi Belajar IPA 
2538 Pengaruh Penggunaan Media Audio Visual Animaker terhadap Motivasi Belajar IPA Siswa Sekolah Dasar - Galuh Maheswari, Puri Pramudiani

DOI $\quad$ : https://doi.org/10.31004/edukatif.v3i5.872

Siswa. Journal Of Educational Science And Technology (EST), 3(1), 9 Https://Doi.Org/10.26858/Est.V3i1.3508

Pebriani, C. (2017). Pengaruh Penggunaan Media Video Terhadap Motivasi Dan Hasil Belajar Kognitif Pembelajaran IPA Kelas V. Jurnal Prima Edukasia, 5(1), 11. Https://Doi.Org/10.21831/Jpe.V5i1.8461

Putri. (2019). Pengaruh Motivasi Belajar IPA Siswa Terhadap Hasil Belajar. EDUKATIF : Jurnal Ilmu Pendidikan, 1(3), 280-286. Https://Edukatif.Org/Index.Php/Edukatif/Index\%0APENGARUH

Putri, E. N. D., \& Desyandri, D. (2019). Penggunaan Media Lagu Dalam Pembelajaran Tematik Di Sekolah Dasar. Edukatif: Jurnal Ilmu Pendidikan, 1(3), 233-236. Https://Doi.Org/10.31004/Edukatif.V1i3.52

Riduwan. (2015). Belajar Mudah Penelitian. Alfabeta.

Sukiyasa. (2018). Media Animasi Dapat Meningkatkan Motivasi Belajar. Jurnal Basicedu.

Syaparuddin, S., \& Elihami, E. (2020). Peningkatan Motivasi Belajar Siswa Melalui Video Pada Pembelajaran Pkn Di Sekolah Paket C. Jurnal Edukasi Nonformal, 1(1), 187-200.

Yusantika, F. D., Suyitno, I., \& Furaidah. (2018). Pengaruh Media Audio Dan Audio Visual Terhadap Kemampuan Menyimak Siswa Kelas IV. Jurnal Pendidikan, 3(2), 252. Http://Journal.Um.Ac.Id/Index.Php/Jptpp/ EISSN: 2502-471X DOAJ-SHERPA/Romeo-Google ScholarIPI\%0ajurnal

Yusup, F. (2018). Uji Validitas Dan Reliabilitas Instrumen Penelitian Kuantitatif. Jurnal Tarbiyah: Jurnal Ilmiah Kependidikan, 7(1), 17-23. Https://Doi.Org/10.18592/Tarbiyah.V7i1.2100

Zayyadi, M., Supardi, L., \& Misriyana, S. (2017). Pemanfaatan Teknologi Komputer Sebagai Media Pembelajaran Pada Guru Matematika. Jurnal Pengabdian Masyarakat Borneo, 1(2), 25. Https://Doi.Org/10.35334/Jpmb.V1i2.298 